\title{
Russia's Legal Transitions: Marxist Theory, Neoclassical Economics and the Rule of Law
}

Simon Deakin

\begin{abstract}
We review the role of economic theory in shaping the process of legal change in Russia during the two transitions it experienced during the course of the twentieth century: the transition to a socialist economy organised along the lines of state ownership of the means of production in the 1920s, and the transition to a market economy which occurred after the fall of the Soviet Union in the 1990s. Despite differences in methodology and in policy implications, Marxist theory, dominant in the 1920s, and neoclassical economics, dominant in the 1990s, offered a similarly reductive account of law as subservient to wider economic forces. In both cases, the subordinate place accorded to law undermined the transition process. Although path dependence and history are frequently invoked to explain the limited development of the rule of law in Russia during the 1990s, policy choices driven by a deterministic conception of law and economics also played a role.
\end{abstract}

Key words: Russia, transition, rule of law, economic theory.

\section{Introduction}

It has often been observed that, in the aftermath of its transition from socialism to capitalism in the 1990s, Russia has failed to become a 'rule of law' state in any generally accepted sense of that term. As a normative goal the 'rule of law' is a 'profoundly contested concept', ${ }^{1}$ but at the level of practice there is general consensus that it is bound up with the idea of legal autonomy, that is, of a legal system which is independent from and placed above both the government and powerful private interests. ${ }^{2}$ In 2014 the World Justice Project ranked Russia 80th. out of 99 countries surveyed for its Rule of Law Index, largely because the Russian judicial system was perceived as being deeply affected by corruption from vested interests and by political interference. ${ }^{3}$ There is a long history of associating the Russian legal system with the instrumentalisation of the state and its subjection to private interests, which some identify with the origins of the Kievan Rus itself. ${ }^{4}$ Others emphasise the comparative isolation of Russia as the rule of law was developing in Europe ${ }^{5}$ and the marginal place of law in society in the early Soviet period, ${ }^{6}$ as well as more recent causes including the corrosion of institutions associated with the Soviet system and the consequences of the privatisations of the 1990s. ${ }^{7}$ In this article we focus on a relatively neglected aspect of this

\footnotetext{
${ }^{1}$ Editorial 2009, p 1; Carothers, 2003.

2 Supiot, 2015, p. 51.

World Justice Project, 2014.

${ }^{4}$ Hedlund 2005 argues that the persistent absence of the rule of law is a factor which has impeded reform in Russia over the centuries.

5 Sachs and Pistor 1997.

6 Macdonald 2011.

${ }^{7}$ On the privatisations of the 1990s, see Glinkina 2004, p 385.
} 
debate, ${ }^{8}$ namely the way in which understandings of the law-economy relation in Russia have been shaped, at critical junctures, by theories and policies premised on the subservience of the legal system to economic forces, and we explore the implications of this for contemporary Russia.

Russia's first transition, from a semi-formed capitalist system to one based on the principles of state-organised socialism, took place in the decade and a half following the revolution of 1917. The second transition, which was initiated by the fall of the Soviet Union in 1992, involved a conscious attempt to (re-)establish a market economy. During both periods, there was considerable interest in and debate over the role of the legal system in the transition process, and attempts to embed the lessons of prevailing theories in the design of legal institutions. Superficially, the dominant conceptions of law in the two transitions - the Marxist theory of law, in the first one, and the neoclassical economic analysis of law, in the second - could not be further apart. At a deeper level, we will suggest, they have much in common. They both view the legal system as the expression of an underlying economic reality and conceive legal change in terms of the alignment of law to that reality. In the context of transition, both saw transformative political action as the principal mechanism of change. In the 1990s as in the 1920s, it was anticipated that the legal system, rather than operating as a mechanism of societal change in its own right, would adjust, ex post, to the transformations initiated in the economic and political spheres. This understanding of the law-economy relation was to have profound implications for the transition process in both periods.

The aim of this paper is to review and compare the experience of legal change in Russia during these two periods of transformation. The story of the Soviet attempt to build a postlegal social order during the 1920s, and of its failure when set against the rise of 'socialist legality' and state planning in the 1930s, generated a large literature beyond Russia in the middle decades of the twentieth century. Our purpose in revisiting the experience of the first transition is not to add to this literature, which was largely concerned with internal debates within Marxist thought and related aspects of legal theory, but to focus attention on ideas and events which, we will suggest, have direct relevance to the experience of transition in today's emerging markets. Thus our contribution is to the study of the role of ideas in the formation of policy and specifically to the part played by economic theory in shaping legal reform in periods of institutional transition. When we set aside the ideological differences between Marxism and neoliberalism, we observe striking continuities in their understanding of the transition process, and we see the same mistakes being made in the (mis)application of economic theory to legal reforms.

We begin by examining in sections 2 and 3 the translation of ideas from economic theory into legal institutions, the difficulties encountered in the operation of those institutions once they were in place, and the eventual outcomes, for each of the two transition periods. In section 4 we review our findings with the aim of obtaining a clearer understanding of the role of law in transitions of whole societies from one dominant mode of economic organisation to another. This issue is of interest in the context of many contemporary societies, sometimes called 'post-transition' systems, which have recently experienced the shift from state ownership and control of the means of production to a market economy characterised by private ownership

\footnotetext{
8 Although see Darden, 2009, on the way in which economic theories including Soviet integralism, liberalism and mercantilism have had a direct impact on policy, including economic policy, in Russia.
} 
of enterprise and the use of markets to achieve resource allocation. How the law functions to encourage and underpin market-based economic relations is still far from being completely understood even in the context of societies which have supposedly reached an 'advanced' or 'developed' level of economic organisation, and our analysis may have implications in these cases too.

\section{The first transition: law and economy in the early Soviet Union}

\subsection{The Marxist theory of law and Soviet legal thought}

Consistently with Lenin's interpretation of Marxist thought, the Soviet system which was put in place following the 1917 revolution was constructed on the principle of government seizure of all revenue-generating property and the regulation of all economic activity. ${ }^{9}$ This was coupled with the subordination of government itself to control by the Communist party elite, consisting of its senior officials (nomenklatura) and security services. Soviet society was modelled along the lines of a consciously teleological project with the achievement of a post-market social order as its goal. ${ }^{10}$ The place of law in this transition was a focus of debates which, while at one level highly abstract and theoretical, also had concrete applications. The leading jurists were actively engaged in law reform initiatives, while politicians, up to and including Lenin and Stalin themselves, publicly commented on legaltheoretical issues which were seen to have a bearing on party dogma.

Marx and Engels had written almost nothing systematic about law, and the subsequent construction of a Marxist theory of law was largely a work of extrapolation from isolated texts, written decades apart. ${ }^{11}$ In the 'Preface' to the Contribution to a Critique of Political Economy, ${ }^{12}$ written in 1859, Marx had referred to the 'social relations of production' as 'the economic structure of society, the real foundation, on which rises a legal and political superstructure'. The same passage had described 'property relations' as a 'legal expression for' the social relations of production. These remarks came to be interpreted as the basis for a 'materialist' theory of law which regarded legal concepts and processes as expressions of a deeper reality consisting of economic relations.

In 1875, in a communication to the organisers of the Gotha unity congress which led to the formation of the German Socialist Workers' Party, which was eventually published in 1891 under Engels' instruction as The Critique of the Gotha Programme, ${ }^{13}$ Marx and Engels had written that in the 'first phase' of a communist society which would emerge 'after prolonged birth pangs from capitalist society', law could not 'be higher than the economic structure of

\footnotetext{
${ }^{9}$ Although this did not quite result in the elimination all forms of market-like exchange in the formal part of the Soviet economy: see for example Harrison (ed.) 2008 on arms procurement under Stalin. Even the Communist Party of the Soviet Union was subject to budget constraints and from about 1948 was 'run as a serious business with attention to both revenues and expenditures' with revenues derived principally from membership dues and publishing: Belova and Lazarev 2012. The presence of budget constraints does not however imply that the Soviet Union functioned anything like a modern market economy.

10 Reddaway and Glinski 2001, p 26.

${ }^{11}$ Although Engels had an interest in the development of legal institutions: see Engels 1884.

${ }^{12}$ Marx 1859, p 24.

13 Reproduced in Marx and Engels 1977, pp 13-30.
} 
society and its cultural development conditioned thereby'. The 'narrow horizon' of bourgeois law could only be overcome, they wrote, in a 'higher phase' of society in which 'the productive forces have... increased with the all-around development of the individual, and all the springs of co-operative wealth flow more abundantly'. This would be a society organised according to the principle, 'from each according to his ability, to each according to his needs'. ${ }^{14}$ This passage came to be read as implying, by Soviet jurists among others, that in the transition from capitalism to communism, law, as an expression of capitalist economic relations, would gradually fade or 'wither' away.

The use of Marxist theory to develop a 'general theory' of law, that is to say, one capable of identifying the nature of law and of explaining the functioning of the different branches and subdivisions of the legal system, was the distinctive contribution of the Soviet jurist Evgeny Pashukanis in his landmark text The General Theory of Law and Marxism, first published in 1924. ${ }^{15}$ The General Theory became the basis for the leading school of thought in Soviet legal analysis during the late 1920s and early 1930s, and Pashukanis played a prominent role in drafting laws and in the administration of the legal system at this time. Pashukanis's book owed its wide influence to a number of factors, not least the striking critique it offered of law and capitalist economic relations, which resonated beyond the borders of the Soviet Union and was acknowledged at the time and subsequently as a significant contribution to legal theory. ${ }^{16}$ Of more immediate relevance to our current argument, Pashukanis succeeded, at least for a while, in articulating a theory of law which matched the political needs of $1920 \mathrm{~s}$ Soviet Russia.

Pashukanis's analysis began where Marx's left off, in emphasising the 'indissoluble internal connection between the categories of the economy based on the commodity and on money, and the legal form itself'. ${ }^{17}$ Private law, which expresses social relations in terms of abstract juridical concepts, is capitalist law, or 'the legal superstructure as such'. ${ }^{18}$ The emergence of this type of legal order is a historically contingent event: 'it is only with the advent of bourgeois-capitalist society that all the necessary conditions are created for the juridical factor to attain complete distinctness in social relations'. ${ }^{19}$ In Pashukanis's account, law is both an expression of the capitalist system and a means of legitimating it, if only on a contingent and temporary basis. Capitalist society is 'above all a society of commodity owners' who must 'recognise in each other the rights of proprietors'. ${ }^{20}$ Commodity owners are 'guided by naked economic calculation' and it is this 'egoism', together with freedom to contract and the 'equality of all human personalities' which make up the social relation of commodity exchange. ${ }^{21}$ The concept of legal personality functions to describe social reality in juridical terms, just as the notion of the 'egoistic, economic subject' operates in political economy. Morality is simply the rule of exchange between commodity owners, and when abstracted from the context of commodity production, the 'basic concepts of morality are meaningless.' It further follows that 'the very concept of justice is drawn from the exchange

14 Marx and Engels 1977, p 16.

15 See now Pashukanis 2009.

16 See, for example, the positive if critical assessments made by Lon Fuller (Fuller 1949, p 1157) and Hans Kelsen (Kelsen 1955).

17 Pashukanis 2009, p 42.

18 Pashukanis 2009, p 41.

19 Pashukanis 2009, p 58.

20 Pashukanis 2009, p 162.

21 Pashukanis 2009, p 161. 
relationship, and expresses nothing outside of it', so that in a capitalist society there are 'no independent and absolute criteria in the idea of justice'. ${ }^{22}$

Pashukanis's identification of autonomous, juridical law with capitalism itself implied a particular theory of the transition process. Pashukanis argued that 'the withering away of bourgeois law (the categories as such, not this or that precept) in no way implies their replacement by new categories of proletarian law'. ${ }^{23}$ Rather, the transition to developed communism should be conceived as the "withering away of the bourgeois form of law as such, as a liberation of that heritage of the bourgeois epoch which is fated to outlive the bourgeoisie itself'. ${ }^{24}$

Pashukanis's theory met the need on the part of the then Soviet orthodoxy to rebut movements within Marxist legal thought which, at the mid-1920s, were arguing for the potential of gradualist legal change to effect a reform of capitalism from within. Addressing the argument ${ }^{25}$ that private law could adjust to reflect the emergence of the modern regulatory and welfare state as a reaction to the extremes of the market order, Pashukanis asserted the need 'to raise one's voice against any attempt to blur over the fundamental contradictions between capitalism and socialism, to veil, with the help of cleverly devised "transformations of civil law", the class nature of capitalist private property and to attach the label of a "social function" to it'. ${ }^{26}$ The transition process had to involve radical political change of the kind experienced in Soviet Russia after 1917: 'the anti-social aspects of private property can only be eliminated de facto, that is, by the development of the planned socialist economy at the expense of the market economy'. ${ }^{27}$

At the same time, Pashukanis's theory offered a rationale for the survival of certain aspects of bourgeois (or private) law, along with private property relations, in the early years of the Soviet Union. The New Economic Policy (NEP) of the early 1920s had involved an acceptance of a continuing role for private enterprise and production, in an attempt to achieve a basic level of economic growth after the privations of the civil war period which ended in 1922. ${ }^{28}$ The NEP was a 'tactical retreat' which was justified by the impossibility of Russia passing directly from a semi-feudal society to a socialist one, without first experiencing a form of market economy, however limited. ${ }^{29}$ The Civil Code of 1922 recognised the right of all citizens 'to choose any occupation and profession not prohibited by law, to acquire and alienate property within the limitations established by law, to enter into legal transactions and to incur obligations, and to organise industrial and commercial enterprises in compliance with all decrees regulating industrial and commercial activities and protecting hired labour' (Article 5) and also stated that 'no-one may be deprived of civil-law rights or limited in rights except in the cases and in the manner prescribed by the law' (Article 6). According to the

${ }^{22}$ Ibid.

23 Pashukanis 2009, p 61

24 Pashukanis 2009, p 63.

25 Made by Karl Renner in Renner 1929, first published in 1904; see Renner 1949.

${ }^{26}$ Pashukanis 2009, p 35.

27 Pashukanis 2009, p 99.

${ }^{28}$ Under a decree of 10 April, 1923, corporations were permitted to operate within certain financial limits, although there is evidence that the regime found these to be a potential threat and confusion about the appropriate role of the capitalist corporation continued until the end of the NEP: see Owen1991.

${ }^{29}$ See Head 2008, ch 6. 
senior Soviet jurist at the time of the Code's drafting, Pyotr Stuchka, the Code was 'the economic policy of our transition period, or more precisely the NEP, put into the form of articles of law'.

These protections were nevertheless qualified by Article 1 of the Civil Code which stated that 'civil-law rights shall be protected by law, except in those instances where they are exercised in contradiction to their socio-economic purpose', while Article 4 referred to private rights and obligations being granted 'for the purpose of the development of the productive forces of society'. Stuchka referred to these provisions as a 'sword of Damocles', making both civil rights and legal capacity contingent on an ill-defined state policy. ${ }^{31}$ The Civil Code was characteristic of measures at this time which were a hybrid of pre-revolutionary legal models and an emerging model of Soviet law which was to expose the fault lines in the theory of transition.

\subsection{From 'revolutionary legality' to 'Soviet law'}

In the immediate aftermath of the Bolshevik coup in 1917, the concept of 'revolutionary legality' was used to articulate the principle that legal rights of all kinds were to be subordinated to the purposes of the revolution. Decree no 1 published on 7 December 1917 abolished the Tsarist legal system, the Procuracy and the Bar, and introduced a new system of revolutionary tribunals and people's courts, with the intention of enabling citizens to settle their disputes simply. ${ }^{32}$ An administrative decree of 1919 stated that the role of the criminal law was to defend the social structure of existing society against violations by repressive measures. However it failed to list those offences that were considered to be crimes and left it to the discretion of the judge to decide whether an act was dangerous to society. The same decree also provided that punishments should not be used to inflict injurious or needless suffering, but this only applied in the case of 'non-political' offences such as theft. ${ }^{33}$ The Criminal Code of 1926 stipulated that 'if any socially dangerous act has not been directly provided for by the present code, the basis and extent of liability for it is determined by applying to it those articles of the Code which deal with offences most similar in nature.' A 'socially dangerous act' meant any act which could be 'dangerous' to the revolution. ${ }^{34}$

Pashukanis's theory saw criminal law under capitalism as a mechanism used by bourgeois society to support the class system, that is, as a manifestation of organized class violence. The criminal process was a variant of commodity exchange, reflecting the principle of equivalence: 'the prosecutor, as expected of a "party", asks a "high price"..... the criminal seeks leniency, a "discount", the judge decrees "according to justice", ${ }^{35}$ Under the bourgeois criminal justice system, the degree of punishment varied according to the extent of intentionality or responsibility; the idea of responsibility reflected the sense of 'punishment... as a method of payment'. Thus the criminal law 'like the law in general, is a form of

${ }^{30}$ Cited in Head 2008, p 127.

31 See Gsovski 1938, p 27.

${ }^{32}$ Smith 1996, p 29.

33 Hostettler 2003, p 30.

34 Johnson1969, p 9.

35 Pashukanis 2009, pp 168-9. The assimilation of criminal laws to prices has been promoted more recently by Gary Becker of the Chicago school (Becker 1968, p169), but without allusion to Pashukanis' analysis of forty years earlier. See further our discussion of Becker's 'economic approach' in section 3, below. 
intercourse between isolated egoistic subjects'; as crime and punishment were 'necessary determinants of legal form', their gradual disappearance in the transition from a market society would be 'the surest sign that the narrow horizon of bourgeois law is finally opening up before us'. ${ }^{36}$ Conversely, the practice of revolutionary legality in the administration of the criminal law could be justified as a form of 'social defence' which was 'regulated by technical rules' rather than by 'legal principle'.

But as the course of Soviet economic and legal development unfolded, it became more difficult to maintain the view that legal structures were 'withering away'. Stuchka's 1927 article 'Soviet law' argued that because of 'the extreme length of the transitional period there has naturally been formed a special Soviet law for the transitional period. This obviously contains elements of bourgeois law, but in essence it introduces profound changes into all social relations, including law'. ${ }^{38}$ In 1928 the first five-year plan was initiated, and the mixed economy of the NEP formally repudiated. By 1932 private ownership and trade had been almost entirely suppressed, at least with respect to the formal economy. Pashukanis's commodity exchange theory came increasingly into conflict with an emerging concept of Soviet law which was distinct from 'bourgeois law'.

The question of how to interpret the persistence of law in the transition period turned on the nature of the relationship between the economic 'base', consisting of the social relations of production and other aspects of material social reality, and the 'superstructure' of which the legal system was deemed to be a part. This implied that there was a limit to how far law could be used as an instrument of social change during the transition period; law was essentially a reflection of economic relations. Consistently with the view expressed by Marx and Engels on the transition process, ${ }^{39}$ Pashukanis argued that the legal form could only be transcended through 'the gradual transition from equivalent distribution... to the formula of developed communism'. ${ }^{40}$

Although the withering away of law would begin as soon as power had been wrested from the ruling class, it would not be completed overnight; moreover, in Marxist terms, the process was to be thought of as a dialectical one. Thus while, over the long run, law reflected the economy, at particular conjunctions law could influence economic and social developments. Engels had suggested that 'the various elements of the superstructure', including 'juridical forms', would 'exercise their influence over the course of the historical struggles and in many ways determine their form in particular'. ${ }^{41}$ Engels also thought that while law expressed economic relations in general terms, the need for juridical order meant that it was constrained to do so in an 'internally consistent way' which implied some departure from the 'faithful reflection of economic conditions'. ${ }^{2}$ This opened up a space for legal autonomy and

36 Pashukanis 2009, p 188.

37 Pashukanis 2009, p 133.

38 Cited in Head 2008, p147.

39 Marx and Engels 1977; see above.

40 Pashukanis 2009, p 131.

41 Friedrich Engels, 'Letter to J. Bloch, 21 September 1890', in Marx and Engels, Selected Correspondence, 1942, at pp. 394-5, cited in Head 2008, p 32.

42 Friedrich Engels, 'Letter to Conrad Schmidt', 27 October 1890, in Marx and Engels, Selected Correspondence, at p. 402, cited in Head 2008, p 32. In 'Ludwig Feuerbach and the End of Classical German Philosophy', published in Die Neue Zeit in 1886, Engels wrote: 'the economic facts must assume the form of juristic motives in order to receive legal sanction; 
therefore, by extension, for the preservation of a role for the legal system after the inception of the socialist state. Lenin had written that in a state formed by a socialist revolution, law would begin to 'wither away immediately', but he had also stated that the bourgeois state would only disappear once 'the possibility of exploitation no longer exists anywhere'. ${ }^{43}$ Exactly what Lenin had meant when, in a similar vein, he had written that 'under communism not only does bourgeois law remain for a certain time but so does the bourgeois state, without the bourgeoisie', ${ }^{44}$ was a matter of much dispute among jurists during the 1920 s. $^{45}$ In the General Theory, Pashukanis argued that while 'seizure of political power by the proletariat is the fundamental prerequisite of socialism', the experience of transition had shown that 'planned production and distribution cannot replace market exchange and the market as the link between individual economic units overnight'. Relations between stateowned enterprises and smaller firms would continue to be governed by contractual relations during the transition period even though in this case the legal form 'exists for the sole purpose of being utterly spent'. ${ }^{46}$ Pashukanis envisaged empirical research being conducted to track the transition process in which the commodity form would be transcended and the legal superstructure would progressively dissolve,${ }^{47}$ a project that was never fulfilled.

In 1930, Stalin's speech to the Sixteenth Party Congress addressed the issue explicitly, in a way which cast doubt on the feasibility of law's disappearance:

We are for the withering away of the state, and at the same time, we are for the strengthening of the dictatorship of the proletariat, which represents the mightiest and most powerful authority of all forms of state that have ever existed. The highest development of the state power for the purpose of preparing conditions for the withering away of state power... this is the Marxist formula. ${ }^{48}$

In this vein, Pashukanis's 1932 article 'Theory of State and Law' argued that Soviet law, in protecting 'the interest of the working majority, the suppression of class elements hostile to the proletariat, and the defence of socialist construction' was 'radically different from bourgeois law, despite the formal resemblance of individual statutes' ${ }^{49}$ His 1935 textbook on Soviet economic law still rejected the concept of 'proletarian law', but did acknowledge the idea that Soviet law expressed the interests of the working class as the ruling class under socialism. ${ }^{50}$ In a 1936 paper he referred to the 'mistake' of arguing that law was a bourgeois form that 'cannot be filled with a socialist content and which must wither away in proportion to the realisation of such content' in favour of arguing that Soviet law was 'the law of the

and since, in so doing, consideration of course has to be given to the whole legal system already in operation, the juristic form is, in consequence, made everything and the economic content nothing. Public law and private law are treated as independent spheres, each being capable of and needing a systematic presentation by the consistent elimination of all inner contradictions' (Engels 1946).

43 Lenin 1964, p 488. See the discussion of Head 2008, p 52.

${ }^{44}$ Lenin 1970, p 138.

45 See Head 2008, p 51.

46 Pashukanis 2009, p 133.

47 Ibid.

48 Reproduced in Beirne and Sharlet (eds.) 1980, p 234.

49 Beirne and Sharlet (eds.) 1980, p 297.

50 Beirne and Sharlet (eds.) 1980, p 305. 
proletarian state which serves as an instrument in the construction of socialism'. ${ }^{51}$ The shift towards 'socialist legality' culminated in the 1936 Constitution, which according to Pashukanis's critic Vyshinsky signified that 'under socialism... law is raised to the highest level of development'. ${ }^{52}$

Pashukanis was arrested in January 1937 and was executed shortly afterwards. His place as doyen of the Soviet legal profession and principal spokesman on legal theory was taken by Vyshinsky, who had earlier been a prosecutor in the show trials of the 1930s. Vyshinsky adhered to the notion that formal law was subordinate to the law of the revolution, so that 'collisions must be solved only by subordination of the formal commands of the law to those of party policy'. 53

\subsection{The demise of Soviet law}

In his report on the draft 1936 Constitution, Stalin declared that 'the complete victory of the socialist system in all spheres of national economy is now a fact.' This meant 'that the exploitation of men by men has been abolished, eliminated, while the socialist ownership of the implements and means of production has been established as the unshakeable foundation of our socialist society'. ${ }^{54}$ At the same time, the Constitution embodied a principle which Stalin referred to as the "stability of the laws'. ${ }^{55}$ Writing from exile in 1937, Trotsky commented that that the Soviet state, far from withering away, had 'grown into a hitherto unheard of apparatus of compulsion'. ${ }^{56}$ Thus the legal theory of transition contributed to the emergence of a jurisprudence of terror; Pashukanis's attempts to redefine the state during the transition period in accordance with the Stalinist conception of socialist legality, at the same time as maintaining his view of criminal law as withering away to technical rules designed to protect society, opened the door to a vague and flexible 'Soviet criminal policy' in which the judicial process was subordinated to political ends. Soviet law, although clothed by the notion of 'socialist legality', became little more than the expression of the will of the partystate, while Soviet legal theory was reduced to a 'vulgar neo-positivist jurisprudence'. 57

After the terror of the purges subsided and the Soviet society recovered from wartime devastation, the formal economy was run as a command system. The state sector coexisted, however, with a large informal economy in which criminal interests were intermingled with those of the nomenklatura. The inability of the legal system to uphold basic entitlements contributed to the creation of a series of informal and quasi-normative systems which were not sponsored by the state, and were largely antagonistic to the teleological project which the state continued to maintain, but which constituted the rules according to which much of society actually functioned. Breaking down these systems and substituting them with the official legal system became one of the main obstacles to reform. Hopes were placed in the 'emergence of a superior type of Soviet man" ${ }^{, 58}$ who would be both spontaneously more

51 Beirne and Sharlet (eds.) 1980, p 314.

52 Cited in Berman 1963, p 55.

53 Andrey Vishinsky, 'Zakonnost Revolutsionnaya', in: 26 Bolshaya Sovietskaya

Entsiklopedia (1933), p. 86, cited in Guins 1954, p 73.

54 Cited in Head 2008, p 149.

55 Cited in Head 2008, p 150.

${ }^{56}$ Cited in Head 2008, p 109.

57 Beirne and Sharlet, 'Introduction', in Beirne and Sharlet (eds.) 1980, p 34.

58 Feldbrugge, 1993, p 45. 
compliant as well as more productive than his non-Marxist counterpart. In practice, it was the limited efficiency of the economy rather than inherent deficiencies in human psychology which ensured that 'devotion to social interests, readiness to privation and harsh discipline instead of private interest, self-concern and freedom of choice ${ }^{59}$ characterised economic life in the Soviet Union. Even before the political collapse of the early 1990s, the Soviet system was failing economically. ${ }^{60}$ The transition process, along with 'Soviet law', had reached a dead end.

\section{The second transition: neoclassical law and economics and 'shock therapy' in the 1990s}

\subsection{The law and economics of transition}

The fall of the Berlin Wall in 1989 was welcomed in Europe and America as signifying 'not just the end of the Cold War, or the passing of a particular period of postwar history' but, more fundamentally, 'the end of history as such: that is, the end point of mankind's ideological evolution and the universalisation of Western liberal democracy as the final form of human government'. ${ }^{61}$ For the states of the former communist bloc, this implied a second transition, away from state ownership and organisation of the economy, towards a marketbased social and economic order. Neoclassical economic theory provided the intellectual bedrock for this process. Neoclassical theory was already the dominant paradigm in economics and increasingly influential across the social sciences and in legal analysis; it received further legitimation from the fall of communism.

At the core of neoclassical economics is a set of interlocking axioms concerning human behaviour and social structure. In the influential formulation offered by the Chicago-based economist Gary Becker in The Economic Approach to Human Behavior (1976), economic analysis is founded on 'the combined assumptions of maximising behaviour, market equilibrium and stable preferences', which, if applied 'relentlessly and unflinchingly', can be used to explain a wide range of social institutions, including, but not limited to, those conventionally identified with the 'market sector'. ${ }^{62}$ The assumptions of maximisation and preference stability combine to form the rational actor model, which posits that voluntary trades made by individuals reflect their subjective wants. The market equilibrium assumption maintains that prices and related market mechanisms operate to allocate the scarce resources of a society in a value-enhancing or, in some versions, optimising way. Becker himself accepted that not all participants in a market 'necessarily have complete information or engage in costless transactions', ${ }^{63}$ but declined to draw the conclusion that these imperfections subverted the assumption of equilibrium. In this he was following the example of the neoclassical mainstream which, in the middle decades of the twentieth century, was preoccupied with modelling the mathematical properties of markets characterised by perfect competition. ${ }^{64}$ This body of work had a normative dimension, since it could be deduced from the operation of basic axioms that in economies defined by stable market equilibria, resources would be allocated to their most efficient use, and that the aggregate well being of all market

${ }^{59}$ Guins 1954, p 82.

60 Reddaway and Glinski 2001, ch 2.

${ }^{61}$ Fukuyama1989, p 1.

62 Becker 1976, p 5.

${ }^{63}$ Becker 1976, p 6.

${ }^{64}$ The high water mark of this approach was Arrow and Hahn 1971. 
participants would thereby be maximised. It was a short step from these 'fundamental theorems ${ }^{, 65}$ to the conclusion that competitive markets represented the optimal design mode for the economy and, more generally, for social institutions characterised by explicit or implicit price effects, which in Becker's view was, presumptively, all of them, including the state and the family.

The mathematical formalisation of the model of market equilibrium had only been achieved by putting to one side questions of the role of the legal system and other aspects of the institutional environment in underpinning exchange relations. From the early 1960s onwards, however, a body of work developed which addressed the role of law in a market-based economy in a more systematic way. This departed from the assumption of costless contracting which was inherent in equilibrium-based modelling, and in so doing assigned a role to the law and related institutional mechanisms in reducing or otherwise mitigating the effects of transaction costs and related barriers to efficient exchange. R.H. Coase's article 'The Problem of Social Cost', published in $1960,{ }^{66}$ was the first step in this process, which was to lead to the emergence in the 1970 s of the neoclassical economic analysis of law ${ }^{67}$ or, as it became known, 'law and economics', the field defining itself as 'the application of economic theory and econometric methods to the formation, structure, processes and impact of law and legal institutions'. ${ }^{6}$

Coase is generally taken to have shown in 'The problem of social cost' that legal rules assigning rights and liabilities between private economic actors can address externalities (unbargained for third-party effects which prevent optimal resource allocations) more effectively than government action such as regulation and taxation. The so-called 'invariance theorem' presented by Coase (although not named as such by him ${ }^{69}$ ) predicts that in a world of zero transaction costs, however legal rights are initially assigned, the parties will bargain their way to an efficient allocation which maximises their joint product. One reading of the Coase theorem, although by no means the only possible one, is that as long as legal rights of some kind are assigned to the parties, it does not matter, from the point of view of efficiency, who acquires them. ${ }^{70}$ The principal role of the law is to assign the 'property rights' which form the building blocks of economic exchange. It is clear from the text of 'The problem of social cost' that the 'invariance theorem' only holds if contracting is costless: 'the ultimate result... is independent of the legal position if the pricing system is assumed to work without cost ${ }^{71}$ Coase subsequently emphasised that his approach was not concerned with the

65 The first of the two 'fundamental theorems' of welfare economics holds that a market equilibrium will result in a Pareto-optimal allocation of resources, that is to say, one in which there is no further scope for distributional changes that improve the welfare of some agents without imposing losses on others. The second theorem, which is the converse of the first, states that assuming consistent preferences ('convexity'), any Pareto-optimal allocation can be modelled as a competitive market equilibrium. This is widely taken to mean that policy makers should 'let the market work' in order to arrive at allocations which maximise resource efficiency. See Varian 1974, p 223.

${ }^{66}$ Coase 1960, p 1.

67 Posner 1970.

68 Mackaay 1995, p 65.

69 The invention of the term 'Coase theorem' appears to be attributable to George Stigler: Stigler 1966, p 113.

70 On the range of possible interpretations of the Coase theorem, see Cooter 1982, p 1.

71 Coase 1960, p 8. 
properties of this zero transaction cost world, a state of affairs which he regarded as both empirically implausible and logically impossible. ${ }^{72}$ Instead, he argued for a research project which would look at ways in which institutions of different kinds responded to the presence of transaction costs in particular settings. In the positive transaction cost world, which is the actual one, there is no necessary relationship between efficiency and private law; whether private law solutions offer better outcomes, from an efficiency perspective, than regulation or taxation is, in the end, a question for empirical analysis. ${ }^{73}$

In the former communist bloc after the fall of the Berlin Wall, policy took the form of "the administrative imposition of standards of economic development considered to be "Western" and [hence] universally applicable'. ${ }^{74}$ In fact, neoclassical economic theory did not have a well worked-out position on how a market economy might be instituted, as opposed to how it worked once it was in place. Writing in 1992 about the transition to a market economy in central and eastern Europe and the former Soviet Union, Coase commented that 'if we knew more about our own economy, we would be in a better position to advise them'. ${ }^{75}$ Instead, a simplified version of the Coase theorem was advanced as the basis for structural reform, according to which it was essential to initiate the transition process by dismantling state ownership and regulation of the economy, and re-establishing private property rights as the basis for exchange. The 'invariance theorem' was invoked to support the claim that it did not matter how property rights were allocated; as long as they were clearly assigned, bargaining would ensure that they were subsequently directed towards their most efficient use. ${ }^{76}$

It was argued that the process of liberalisation did not need to wait until the institutions of the market, including a functioning system of private law, were fully in place. ${ }^{77}$ Instead, once the transition process was initiated, property owners would begin to demand the protections which the law was able to provide. ${ }^{78}$ It would therefore be better to allow the legal system and related institutions to emerge spontaneously in response to the changing structure of the economy than to impose a particular model of legal ordering at the outset. ${ }^{79}$ According to the neoclassically trained advocates of mass privatisation in Russia, the 'consumers' of legal rules in a market-based economy - individuals and businesses - would rationally demand

72 Coase 1960, p 15.

73 Coase 1992, p 718.

74 Reddaway and Glinski 2001, p 12.

75 Coase 1992, p 714. To similar effect is the comment of the economist and Nobel Laureate Douglass North (North 2005, p 65) to the effect that 'Neo-classical economic theory provides an understanding of the operation of markets in developed economies but was never intended to explain how markets and overall economies developed'. For discussion of North's views on institutions and development, see Faundez 2014.

76 For (critical) discussion of this tendency, see Stiglitz 1994.

77 Boycko et al. 1995.

78 See Freeland 2005, p 52: 'Ideally, the reformers would have liked instantly to force out the communist industrial elite and usher in a new capitalist one. But if that wasn't possible it didn't worry them too much. The main thing was to create a capitalist system: it didn't really matter who the capitalists were. For them, transforming Russia was sort of like writing a computer program. As long as they got the program right - as long as they created the proper capitalist incentive structure - everything else would automatically fall into place.'

${ }^{79}$ A related motivation of reformers was the desire to dismantle the system of state planning in order to forestall any possible restoration of the Soviet system: Freeland 2005, p 19;

Roland 2000, p 85. 
legal protection for property and contract rights, which, in turn, would be supplied by the legal system. ${ }^{80}$ Thus the precise content of private law rules mattered less, to begin with at least, than the fundamental 'structural' reform of moving to an economy based on private property and freedom of contract.

The reformers did not advocate a legal vacuum; it was acknowledged that a well functioning court system would be needed to assist the move to the market. Theory suggested that legal structures in the early stages of the transition should be as 'simple' as possible. Richard Posner, leading exponent of Chicago-school law and economics and already at that stage an experienced appellate-level judge in the US federal court system, influentially argued that the appropriate legal framework for transition systems would be one based on 'bright-line rules' which could be easily applied, as opposed to 'principles' which it would be open to courts to interpret in a flexible way. Relatedly, he suggested that the reform process should focus on the creation of 'rules' from which a large number of economic actors would benefit immediately, rather than 'institutions' which would be expensive and time-consuming to create. $^{81}$

\subsection{Economic theory and 'shock therapy'}

Neoclassical law and economics dovetailed with more general arguments for the efficiency of market-based economic ordering to justify a transformative programme of 'shock therapy' which began almost immediately following the disintegration of the Soviet Union in the summer of 1991. The origins of the policy lay in a report on the Soviet economy jointly prepared by the IMF, OECD and EBRD in January 1991. This argued for rapid price liberalisation and privatisation, and for a macroeconomic policy based on tight control of the money supply, high interest rates and 'hard budget constraints' for the public sector. In December 1991 a decree removed controls on $80 \%$ of producer goods and $90 \%$ of consumer goods. In January 1992 a free trade decree abolished the permit system which had previously controlled the trading of goods. A programme of mass privatisation of state-owned enterprises was initiated from the autumn of 1992. Each Russian citizen was assigned a privatisation voucher worth 10,000 roubles (then equivalent to \$20). Vouchers could be sold, exchanged for shares in privatised companies, or invested in collective investment vehicles known as 'voucher funds'. By the end of December 1992 47,000 state-owned companies had been privatised, and a year later the figure had reached $90,000 .{ }^{82}$

${ }^{80}$ Boycko et al. 1995. As Stiglitz has observed, the application of the neoclassical model of utility maximisation could lead individuals to vote rationally to "postpone the establishment of the rule of law state': Hoff and Stiglitz 2004. The creation of a constituency for reform may have been seen by the economic advisers to the government as preferable to reform exclusively from above, but it nevertheless failed to result in the legal and institutional change which was anticipated. This supports one of the contentions of this paper, to the effect that although neoclassical economics, with its emphasis on private contracting, presupposes and requires a properly functioning system for the protection of property and contract rights, it nevertheless sees this system as subordinate to and responsive to the market. This gives rise to the difficulty of using the law to restrain the excesses of less scrupulous market-makers, and highlights the somewhat circular perception of the market as both a force for change of the legal and institutional framework at the same time as relying on that framework in order to function properly.

${ }^{81}$ Posner 1998, p 1.

${ }^{82}$ Boycko et al. 1995. 
Rapid transition was supported by the IMF, western countries and the Yeltsin government on the grounds that it would prevent the reconstruction of the Soviet state apparatus. Yeltsin's government took the view that a top-down transformation of the economy would provide the stimulus needed to initiate the move to a market economy: 'free prices must become the means to achieve a growth in production, and this will in future set a limit to price increases' ${ }^{83}$ Once state planning was abolished and government itself made subject to market forces, 'rational' economic behaviour would follow, and a market equilibrium achieved: 'the government must limit its activity in the economic sphere to the maximum extent possible and let the market, money and entrepreneurs work' ${ }^{84}$

In practice, many of the voucher funds set up to channel investments in privatised companies turned out to be pyramid schemes, and most paid no dividends. The trading of vouchers resulted in the concentration of ownership in the hands of the former managers and civil servants who were now running most of the former state-owned enterprises, but fewer than $14 \%$ of privatisations took the form of public auctions in any event. Most were arranged bilaterally under the supervision of the government-run State Property Management Committee, chaired by the minister and free-market advocate, Anatoly Chubais. The emergence of a small group of economic 'oligarchs', named as such by the former Soviet dissident Alexander Solzhenitsyn in a speech to the Russian parliament as early as October $1994,{ }^{85}$ was consolidated by the 'loans for shares' scheme initiated in 1995, under which the government transferred shares in state-owned enterprises to banks and other private-sector entities owned or controlled by a number of oligarchs as security for loans. When the loans were not repaid on time, the lenders retained the shares. ${ }^{86}$

The immediate impacts of 'shock therapy' included record price inflation and a dramatic drop in GDP. ${ }^{87}$ Neoclassical economic theory was invoked to justify the overall direction of policy. Since the laws of economics were 'like the laws of engineering' so that 'one set of laws works everywhere', ${ }^{88}$ the market itself could not be to blame. Empirical research carried out in the immediate aftermath of the fall of the Soviet Union had suggested that 'Soviet man' was really 'economic man' at heart and would respond to market incentives in

83 Yeltsin speech, cited in Reddaway and Glinksi 2001, p 233.

${ }^{84}$ Sergei Vasiliev, cited in Reddaway and Glinksi 2001, p 247. Although the Russian government was advised by Western economists and institutions in the early stages of transition, Egor Gaidar maintained that they were making their own decisions, and not merely following advice: Gaidar 2003, p 117.

${ }^{85}$ Reddaway and Glinksi 2001, p 278.

${ }^{86}$ The 'loans for shares' scheme has been described by Chrystia Freeland in Freeland 2005 as 'both the cause and symbol' of the malaise of the Russian market economy although for a more recent argument that its significance has been overstated: Treisman 2010.

${ }^{87}$ Consumer prices rose by 1,345\% in the first year of shock therapy after August 1991. Price inflation was $896 \%$ in $1993,220 \%$ in $1994,190 \%$ in 1995 and still $48 \%$ in 1996 . A principal cause of rising prices was a collapse in industrial production from 1992 onwards. Real wages fell by $25 \%$ during 1992-1996 and again by $42 \%$ in 1998-99 following the devaluation of the rouble that was triggered by the Russian government defaulting on its sovereign debt. Between 1992 and 1998, Russian GDP declined by 44\%, industrial production fell by $56 \%$, and capital investment by $80 \%$. By comparison, the fall in Soviet GDP during World War Two had been 24\%. Reddaway and Glinski 2001, pp 249-50. ${ }^{88}$ Lawrence Summers, cited in Hedlund 2005, p 11. 
the expected way. ${ }^{89}$ With the transition process apparently stalling, 'Russian cultural inferiority' ${ }^{90}$ was blamed for the failure of 'market stimuli' to produce 'the expected behavioural changes' on the part of economic actors. ${ }^{91}$ A novel form of social Darwinism was applied to rationalise the 'survival of the fittest' in the harsh transition environment, coupled with the view that 'everything that is economically efficient is morally acceptable'. ${ }^{92}$ Inverting earlier Marxist debates, Russia's 'backwardness' was held to justify a period of 'primitive accumulation' as it sought to catch up with the West. Things were worse than the reformers could have imagined - 'when we placed the patient on the operating table and opened him up, we found that his anatomical structure and internal organs were completely different, of a kind we never encountered" ${ }^{93}$ - but Russia was now in the process of becoming a 'normal country'. ${ }^{94}$ Reforms had if anything been 'too slow and partial'. ${ }^{95}$ Shock therapy was not a mistake, it had not been properly implemented: 'particularly from a structural viewpoint... we needed to reduce aggregate government spending,. 96

\subsection{Corporate governance, ownership concentration and the return of the state}

Gorbachev had initiated law reform in the late 1980s as part of his perestroika programme in an attempt to stimulate the economy, but as in the period of the NEP seventy years earlier the new laws permitting commercial activity, which were inspired by the decrees of the early Soviet government under the NEP, sat uncomfortably with the prevailing communist order. The Soviet system in its final years 'permitted the autocracy to hold a monopoly of political power while allowing a limited amount of autonomy to capitalist energies'. 97 Among these legislative reforms were the Law on Individual Labour Activity in 1986, the Law on State Enterprises 1987, the Law on Cooperative Systems of 1988, the Law on Leasing in 1989 and the Law on Ownership in 1990. Limited commercial activity was thereby encouraged during the perestroika period, but not only was this potentially contradictory from an ideological point of view, it also contravened the criminal law at the time, which still made commercial activity illegal as speculation. However it did help to prepare the way for the more radical reforms that were to follow.

Comprehensive legal reconstruction in post-Soviet Russia emerged in the aftermath of privatisation and market liberalisation, and, like them, was shaped by the logic of an economically-driven transition process. The first part of a new Civil Code was introduced in 1994 and a land code permitting transactions in real property did not come into force until 2001, more than three years after a law allowing mortgages over land. The Joint Stock Companies Law, introduced in 1995, was influenced by the perceived need to have 'simple,

89 Boycko et al. 1999. Although this research had also shown that Russian respondents' expectations of the honesty of businessmen and of the security of private property from state expropriation were significantly lower than those of the Americans who participated in the survey, these differences were largely ignored.

90 Egor Gaidar, cited in Reddaway and Glinski 2001, p 306.

91 Reddaway and Glinski 2001, p 239.

92 Nicolai Schmelev, cited in Reddaway and Glinski 2001, p 239.

93 Jeffrey Sachs writing in Novoye Vremya (1995) No 28, cited in Medvedev 2000, p 84.

94 Shleifer and Treisman 2004.

95 Anders Aslund in 1998, cited in Reddaway and Glinski 2001, p 301.

96 IMF economist Stanley Fischer, cited in Reddaway and Glinski 2001, p 301.

${ }^{97}$ Owen 2001, p 196. 
bright-line rules and strong remedies' ${ }^{98}$ in order to counter 'insider-controlled companies, malfunctioning courts, weak and sometimes corrupt regulators, and poorly developed capital markets'. ${ }^{99}$ The law was designed to be 'self-enforcing' in the sense that would 'minimise reliance on official enforcement" ${ }^{\text {" }} 00$ in favour of harnessing the "monitoring ability of outside shareholders'. External directors and shareholders would 'police the opportunism of managers and controlling shareholders' while the law would 'elicit a substantial measure voluntary compliance' from the latter. ${ }^{101}$ This was to be achieved through a mixture of procedural mechanisms and external control rights modelled on the shareholder-rights orientated models of US and, even more so, UK company law and takeover regulation.

The passage of the Joint Stock Companies Law did not prevent the consolidation of corporate ownership and control in the hands of the new oligarchical elite following the loans for shares scheme. ${ }^{102}$ The trajectory of the oil company Yukos illustrates some of the ways in which the law was circumvented at this time. Yukos was privatised with a multi-layered organisational and management structure. Its principal production subsidiary, Yuganskneftegaz, had its own management organs, and continued to function as a separate organisation. Yukos's new owners faced the challenge of creating a unified company with a single overall administrative framework. Product and revenue streams were first brought under control by forcing the production subsidiaries to sell oil cheaply to the parent company, which then sold it on with a view realising a significant profit (transfer pricing), in the process weakening the position of the subsidiary. Minority shareholders in the production subsidiaries then saw their rights eliminated. This was done by a combination of share dilution, physically preventing minority shareholders from attending meetings, and abuse of the legal process. ${ }^{103}$ The US minority investor, Kenneth Dart, was deprived of his share of Yukos subsidiary profits through transfer pricing. ${ }^{104}$ The 'interested party' provisions of the Joint Stock Companies Law were circumvented by the obscurity of the ultimate shareholding structure, making it impossible to determine whether or not the relevant provisions were actually triggered. The result of this manoeuvring was that Yukos ended up as a coherent vertically integrated structure, ready then to try and improve its image for corporate governance in the realisation that perceived quality of corporate governance has a significant impact on a company's market capitalisation. ${ }^{105}$ Yukos went from one of the most notorious perpetrators of investor rights abuses in 1999, to lead the growth in the corporate governance ratings of the Russian Institute of Corporate Law and Corporate Governance. Over the period from January 2001 to April 2002 its capitalisation grew by 5 times, while during the same period the RTS $^{106}$ index only

98 Black and Kraakman 1996, p 1934.

99 Black and Kraakman 1996, p 1915.

100 Black and Kraakman 1996, p 1940.

101 Black and Kraakman 1996, p 1978.

102 Nor has the corporate legislation always been able to protect the property rights of the owners of businesses: see Firestone 2008, a notorious case being the raid on Hermitage Capital Management, a fund managed by the foreign investor, William Browder.

103 Adachi, 2006, p 65; Black et al. 2000.

104 Heinrich et al. 2007.

105 See Black 2001, p 89, which demonstrates that Yukos and its three production subsidiaries Yuganskneftegaz, Tomskneft and Samaraneftegaz were at the very bottom of the table for quality of corporate governance of 50 major companies in Russia in 1999; Black, Love and Rachinsky 2006.

${ }^{106}$ Russian Trading System, the principal equity index. 
doubled. ${ }^{107}$ The company was transformed from having one of the worst corporate governance records to being one of the best governed (or least that was the reputation it managed to acquire for itself). ${ }^{108}$

One of the aims of rapid privatisation had been to make it infeasible for government to resume a dominant role in economic planning. In the event, the return of the state was not long delayed. Shortly after Putin became president a meeting was held with twenty-one representatives of big business, on 28 July 2000, allegedly to extract from the oligarchs an agreement to stay out of politics, in exchange for which the legitimacy of the privatisations would not be challenged. ${ }^{109}$ It is generally believed that the attack on Yukos by the Russian government from 2003-2005 was a consequence of Khodorkovsky's refusal to abide by the July 2000 agreement to stay out of politics. There may have been another reason, not altogether inconsistent with the first, which is that Putin had a particular vision of how he wanted the Russian economy to be structured, and that Khodorkovsky's intention to sell a major stake in Yukos to an overseas-based multinational oil company was inconsistent with this.

In 1997 Putin had defended a thesis in economics at the St. Petersburg Mining Institute. Although the thesis itself became classified information when he was appointed prime minister in 1999, ${ }^{110}$ Putin also published an article which may be presumed to have reflected the conclusions of the thesis, and which is also consistent with the policy subsequently pursued by his administration in the energy sector. From what it has been possible to glean from reports about the thesis, it considers the importance of natural resources in the development of the St Petersburg/Leningrad region, and the need for strategic planning to develop those resources and the accompanying transportation facilities. Putin's published article argued that, used effectively, mineral resources could provide the basis for Russia's entry into the world economy and for the modernisation of the country's military-industrial complex. This strategy would also, the article argued, promote social stability and raise the well being of the population, critical issues for the state at a period when the transition process has become associated with growing inequalities. Putin advocated the creation of vertically integrated financial industrial groups, supported by state agencies, to compete with Western multinationals, as well as the need to create the right economic conditions for foreign investment in appropriate circumstances. The resources sector was too important to be left to the market while the transition continued: 'a contemporary strategy for rational use of resources cannot be based exclusively on the possibilities of the market. This applies even more to conditions of economic development in a transition, and, thus, to the Russian economy'. ${ }^{111}$

With the state-led dismemberment of Yukos, the second transition had reached a turning point, in very different circumstances from the first one, but equally definitively. As in the 1920s, within a decade or so of the launching of a transformative experiment in economic and social ordering, an alternative pathway for transition was being set out. Russia entered the 2000s under a political leadership determined to reassert the authority of the central state in

107 Guriev et al. 2003, p 8.

108 Heinrich et al. 2007.

109 See Hanson and Teague 2005, p 659; Tomson 2005.

110 Although it is rumoured that an English version of the thesis is available on the internet, our discussion of it is drawn principally from Balzer 2005 and Jack 2004.

111 From Putin's article of 1999, quoted in Balzer 2005. 
the management of the economy, to the extent that it was soon being compared to such earlier models of 'market authoritarianism' as Pinochet-era Chile. ${ }^{112}$

\section{Assessment: identifying the role of legal institutions in economic transition}

Why did the reforms of the 1990s prove to have limited success in implanting notions of legality in economic and business life? The idea that Russia is inherently unsuited to the model of the rule of law relies on broad-brush characterisations which can easily slip into cultural stereotyping of the kind which was widespread among foreign officials and experts in the 1990s. The idea of the rule of law is far from alien to Russian constitutional traditions and practice. The 1993 Russian Constitution declares Russia to be a 'democratic rule of law state ${ }^{113}$ and the term used to express this concept, pravovoe gosudarstvo, has a long history, having been used in the nineteenth century by analogy to the German concept of the Rechtsstaat, and again in the late 1980s during Gorbachev's reforms.

Nor is there evidence to suggest that the rule of law is not valued in Russia. Recent sociological research ${ }^{114}$ suggests that in contemporary Russia there is pent-up demand for the neutral application of legal rules, and for the protection of the legal system to be extended to private citizens in their everyday dealing with business and government. At the same time there is a continuing lack of confidence in law and the legal system among ordinary people in Russia: law is perceived more as a 'sword' than as a 'shield', that is to say, as another weapon in the armoury which can be deployed in conjunction with other methods of persuasion or coercion to achieve a result. Unlike in more established democracies, its role as essentially protective, whether of human rights or of property rights, is not a primary characteristic. Russian courts are perceived as being rigidly bureaucratic, particularly at lower instances, in their interpretation of the law. Judges are career civil servants and the bureaucratic approach appears to be a legacy of Soviet times as well as, in some cases, a result of a lack of a thorough grasp of the implications of market transactions. Although it may contribute to legal certainty, a restrictive or bureaucratic approach to interpretation is a constraint on contractual freedom and therefore freedom of the market. ${ }^{115}$

Meanwhile, market exchange is still highly personalised, and there is a convergence of wealth and power, or in other words of business and the state, which enjoy a mutually beneficial relationship which excludes outsiders. The vast majority of the population, who are outside this elite group, would be powerless to promote or protect their interests, including through the legal system, if they conflicted with the interests of those with wealth, political influence or both. The situation has deteriorated by comparison with the position in

112 Reddaway and Glinski 2001, p 308.

113 Article 1. An alternative term used in the standard English translation of the Constitution (www.constitution.ru) is 'law-bound state'. Gosudarstvo means 'state' and pravovoe is the adjective from the noun pravo, meaning 'law' or 'right' in English which it is argued is closest to the Latin term jus (lex being the equivalent of the Russian zakon, which carries with it the meaning of 'legislation' rather than the rather more abstract 'law').

114 This is a consistent theme in the work of Kathryn Hendley. See in particular Hendley 2009); Hendley 2011; Hendley 2012.

115 Hendley 2011. 
the latter Soviet period, as throughout most of the Soviet period there was little personal wealth and levels of corruption were lower than in contemporary Russia. ${ }^{116}$

There are those who would see an essential continuity between the limited role of legal ordering in contemporary Russia, and the country's long history of weak legal institutions. ${ }^{117}$ Our review of the transition experience in the preceding sections suggests, however, that more specific causes can be identified for the failure of the 'second' transition. ${ }^{118}$ The first relates to the sequencing of economic and legal reform. The policy of transferring ownership to the private sector before an adequate legal infrastructure was in place was expected to stimulate demand for legal reforms, but in fact failed to achieve this: 'the immediate establishment of the rule of law imposes a cost on asset-strippers and some individuals will rationally vote to postpone the establishment of the rule of law state'. ${ }^{119}$ As two of the drafters of the companies law wrote in 2000 , 'the right response may be to stage privatisation and work hard to develop this infrastructure rather than privatise large firms anyway and hope that the outcome will somehow be acceptable'. ${ }^{120}$ The problem was exacerbated by the institution-undermining effects of shock therapy: 'economic revolutions that destroy institutions before new ones can be built are... likely to founder'. ${ }^{121}$ Other commentators have noted the negative consequences of placing economic reform ahead of legal institution building. Improvements in the law came 'too late to further the intended reallocation of rights' once concentrations of power had been allowed to form; the 'new owners of private property' simply failed to demand the 'infrastructural reform' that had been anticipated. Privatisation was 'meaningless if you don't have the rule of law', since the end of state control meant nothing 'if you do not have security of property, if you can't use your property as you want to'. ${ }^{122}$

A second factor was the failure to invest sufficiently in state capacity, or even to maintain such capacity as existed, during the transition period. The drafters of the Joint Stock Companies Law suggested that the error had been to 'underestimate the extent to which functioning law requires honest courts that can redress gross violations' ${ }^{123}$ Courts, they argued, 'were of little help even when self-dealing was obvious'. This view, however, underplays the sense in which the Joint Stock Companies Law was the product of a philosophy which regarded public institutions in general, and in particular those inherited from the Soviet period, were inherently inefficient and corrupt, but which expected private business managers, by contrast, to act on the basis of an enlightened self-interest. A more critical perspective on the assumptions inherent in the neoclassical economic model might have cautioned against the view that 'economic interest is pursued only by comparatively gentlemanly means'. ${ }^{124}$

\footnotetext{
${ }^{116}$ On these points, see Ledeneva and Kurkchiyan (eds.) 2000; Ledeneva 2001; Alena V. Ledeneva, 'Organized Crime in Russia Today' in Galeotti (ed.) 2002; Hendley 2010;

Hendley 2011.

${ }^{117}$ Hedlund 2005.

118 Ibid.

119 Hoff and Stiglitz 2002.

120 Black, Kraakman and Tarrassova 2000, p 1737.

121 Ibid, p 1803.

122 Milton Friedman, writing in his preface to a 2002 World Bank Report: Friedman 2002.

123 Black, Kraakman and Tarrassova 2000, p 1731.

124 Granovetter 1985, p 488.
} 
The chaos and opportunism of the immediate post-Soviet period was fed by the need for the population to adjust from an environment in which entrepreneurial activity was essentially illegal, to one in which almost any profit making activity was de facto permissible, and more unscrupulous elements took advantage of the absence of effective regulation and a proper institutional framework for market activity. ${ }^{125}$ The task of rebuilding Russia became not just one of managing the transition from communism to capitalism, but of creating a functioning market system from the 'economy of collapse' which ensued the collapse of the Soviet system, and which led to ideal conditions for criminals to flourish. ${ }^{126}$ According to an $\mathrm{MVD}^{127}$ investigator, 'Perestroika was the real beginning of organized crime in our country' ${ }^{128}$ and the cause was that 'Russian policymakers committed a fundamental mistake: they tried to develop a free market before constructing a civil society in which such a market could safely operate'. ${ }^{129}$ The policy of reform had overlooked the extent to which so-called 'free markets' in established market economies are in fact highly regulated and benefit from a benign institutional environment in which compliance is the norm. ${ }^{130}$

\section{Conclusions}

In this paper we have argued that the way law is theorised in relation to the process of economic development, and specifically with regard to transition, has a critical role to play in generating a more complete understanding of how market economies are constituted and how they are sustained. In the case of Russia, theories of law and the economy informed the transition process at either end of the twentieth century. These were theories that modelled the legal process in terms of an all-encompassing economic logic, which reduced legal phenomena to economic categories, and assumed, in a deterministic fashion, that legal change was economically driven. In the case of Marxism, the historical-material process of economic evolution in conjunction with revolutionary political change together dictated the form of law. In the case of neoclassical economics, the fundamental axioms of rational economic behaviour and market equilibrium were supposed to perform the corresponding function, in this case creating a demand for market-enabling rules. In the first case the application of Marxist principles in post-revolutionary Russia led eventually to a conception of law that abandoned liberal notions of justice and human rights in favour of revolutionary expediency. In the second case a form of market-enabling legislation was implemented but law failed to emerge and occupy the place it was expected to in a market system. The predicted positive feedback from the economy to the legal system has not materialised, with the result that the legal system is failing reliably to perform what economists perceive as its essential function in a market economy - the protection of property rights together with, more generally, institutional support for market activity.

125 Ledeneva and Kurkchiyan (eds.) 2000; Ledeneva 2001; Ledeneva 2002; Volkov 2002.

${ }^{126}$ Ledeneva and Kurkchiyan (eds.) 2000, p 90.

${ }^{127}$ Ministerstvo Vnutrennikh Del, The Ministry for Internal Affairs.

${ }^{128}$ Handelman 2002, p 86.

${ }^{129}$ Ibid., p 89.

${ }^{130}$ Chang 2010, ch 1. To similar effect, see Knieper 2010, p 115: 'both Japan and Germany share the experience that the market economy is by no means a private, spontaneous affair which breeds its own dynamics intrinsically'. Proposals for the Russian transition put forward by the Japanese industry ministry MITI in 1992 failed to gain significant support: Reddaway and Glinski 2001, p 676. 
The emergence of societies which are now stable rule of law states was undoubtedly turbulent at various stages of their history. In Russia's case, the emergence of the rule of law was hindered by a preoccupation with determinist economic thinking at either ends of the short twentieth century which began with the Bolshevik Revolution and ended with the fall of the Berlin Wall. It is inherent in both Marxism, and the neoclassical economic theory which underpinned reforms in Russia after the fall of communism, that after a period of transition, the ideal form of society will emerge as a natural consequence of the application of the theory. Destined in the first case to 'wither away', and in the second to develop spontaneously in response to demand from an essentially unregulated market, in the event the legal system did neither. In the case of the Soviet Union, the result was a descent into authoritarianism. In the context of contemporary Russia, the rule of law state remains, at best, an unrealised goal. While path dependence may have shaped Russia's transition to a market economy during the 1990s, accounts which stress the role of history and culture risk falling into stereotyping. Specific policy decisions, informed by economic theory which was remote from the realities of transition, played their part in setting Russia on a path which today is far from that envisaged when the reforms of the 1990 s were initiated. ${ }^{131}$

\section{References}

Adachi Y (2006) The Ambiguous Effects of Russian Corporate Governance Abuses of the 1990s. Post Soviet Affairs 22:65

Arrow K and Hahn F (1971) General Competitive Analysis. Holden-Day

Balzer H (2005) The Putin Thesis and Russian Energy Policy. Post-Soviet Affairs 21:210

Becker G (1968) Crime and Punishment: An Economic Approach. Journal of Political Economy 76:169

Becker G (1976) The Economic Approach to Human Behavior. University of Chicago Press

Beirne P and Sharlet R (eds.) (1980) Pashukanis: Selected Writings on Marxism and Law. Academic Press

Belova E and Lazarev V (2012) Funding Loyalty: The Economics of the Communist Party. Yale University Press

Berman H (1963) Justice in the USSR: An Interpretation of Soviet Law. Harvard University Press.

Black B and Kraakman R (1996) A Self-Enforcing Model of Corporate Law. Harvard Law Review109:1911

131 The second Russian transition took place under conditions of extreme turbulence and it is only with the benefit of hindsight that we are now in a position to assess the full effects of decisions taken in the mid-1990s. Thus we wish to emphasise that it is not our intention to add to accounts which have sought, wrongly in our view, to apportion blame to individual reformers. 
Black B, Kraakman R and Tarassova A (2000) Russian Privatization and Corporate Governance: What Went Wrong? Stanford Law Review 52:1731

Black B (2001) The Corporate Governance Behavior and Market Value of Russian Firms. Emerging Markets Review 2:89

Black B, Love I and Rachinsky A (2006) Corporate Governance and Firms Market Values: Time Series Evidence from Russia. Emerging Markets Review 7: 361

Bouckaert B and De Geest G (eds.) (1995) Encyclopaedia of Law and Economics. Edward Elgar

Boycko M, Shleifer A and Vishny R (1995) Privatizing Russia. MIT Press

Boycko M, Shiller R and Korobov V (1991) Hunting for Homo Sovieticus: Situational versus Attitudinal Factors in Economic Behavior. Brookings Papers on Economic Activity 1:127

Carothers T (2003) Promoting the Rule of Law Abroad: The Problem of Knowledge. Carnegie Endowment for International Peace 34

Chang H-J (2010) 23 Things They Don't Tell You About Capitalism. Penguin Books Coase R (1960) The Problem of Social Cost. Journal of Law and Economics (1960) 3:1

Cooter R (1982) The Cost of Coase. Journal of Legal Studies 11:1

Coase R (1992) The Institutional Structure of Production. American Economic Review $82: 713$

Darden K (2009) Economic Liberalism and its Rivals. Cambridge University Press

Editorial (2009) The Hague Journal on the Rule of Law 1:1

Engels F (1884) The Origins of the Family, Private Property and the State. Theophania Publishing (2012)

Engels F (1886) Ludwig Feuerbach and the End of Classical German Philosophy. Progress Publishers (1946)

Faundez J (2014) Douglass North's Theory of Institutions: Lessons for Law and Development. Legal Studies Research Paper No. 2014/13, Warwick Law School. Available at SSRN: http://ssrn.com/abstract=2493052 or http://dx.doi.org/10.2139/ssrn.2493052 (last accessed 15 December 2014).

Feldbrugge F (1993) Russian Law: The End of the Soviet System and the Role of Law. Martinus Nijhoff

Firestone T (2008) Criminal Corporate Raiding in Russia. The International Lawyer, Vol 42 No 4:1207 
Freeland C (2005) Sale of the Century: The Inside Story of the Second Russian Revolution 2005. Abacus

Friedman M (2002) Economic Freedom Behind the Scenes. World Bank, Economic Freedom of the World Report 2002.

Fuller L (1949) Pashukanis and Vychinsky: A Study of the Development of Marxist Legal Theory. Michigan Law Review 47:1157

Fukuyama F (1989) The End of History? The National Interest (Summer 1989)

Gaidar E (2003) State and Evolution. University of Washington Press

Glinkina S (2004) How Organized Crime is Hijacking Privatization. 2 Privatizatsiya i Kriminalizatsiya, Demokratizatsiya p 385.

Granovetter M (1985) Economic Action and Social Structure: The Problem of Embeddedness. American Journal of Sociology 91:481

Gsovski V (1938) The Soviet Concept of Law. Fordham Law Review 7:1

Guins G (1954) Soviet Law and Soviet Society. Nijhoff

Guriev S, Lazareva O, Rachinsky A and Tsouhlo S (2003) Concentrated Ownership, Market for Corporate Control, and Corporate Governance. Online at nes.ru/ sguriev/papers/CGRussia.pdf (last consulted 15 December 2014) 8.

Handelman S (2002) 'The Russian Mafia' in Galeotti (ed.), Russian and Post-Soviet Organised Crime. Dartmouth

Hanson P and Teague E (2005) Big Business and the State in Russia. Europe Asia Studies 57: 657

Harrison M (ed.) (2008) Guns and Rubles: The Defense Industry in the Stalinist State. Yale University Press

Head M (2008) Evgeny Pashukanis: A Critical Reappraisal. Routledge

Hedlund S (2005) Russian Path Dependence. Routledge

Heinrich A, Lis A and Pleines H (2007) Factors Influencing Corporate Governance in PostSocialist Companies: An Analytical Framework. William Davidson Institute Working Paper No 896.

Hendley K (2009) "Telephone Law" and the "Rule of Law": the Russian Case. Hague Journal on the Rule of Law 1:241

Hendley K (2010) Coping with Uncertainty: the Role of Contracts in Russian Industry during the Transition to the Market. Northwestern Journal of International Law and Business 30:417 
Hendley K (2011) Varieties of Legal Dualism: Making Sense of the Role of Law in Contemporary Russia. Wisconsin International Law Journal 233

Hendley K (2011) Explaining the Use of Russian Courts. University of Wisconsin Law School, Legal Studies Research Paper Series, Paper No. 1166

Hendley K (2012) Who are the Legal Nihilists in Russia? Post-Soviet Affairs 28:149

Hoff K and Stiglitz J (2002) After the Big Bang? Obstacles to the Emergence of the Rule of Law in Post-Communist Societies. World Bank Policy research Working Paper 2934

Hoff K and Stiglitz J (2004) The Transition from Communism: A Diagrammatic Exposition of Obstacles to the Demand for the Rule of Law. World Bank and Columbia University

Hostettler J (2003) Law and Terror in Stalin's Russia. Barry Rose

Jack A (2004) Inside Putin's Russia: Can There be Reform Without Democracy? Granta Books

Johnson E (1969) An Introduction to the Soviet Legal System. Methuen

Kelsen H (1955) The Communist Theory of Law. Stevens and Sons Limited

Knieper R (2010) Pulls and Pushes of Legal Reform in Post-Communist States. Hague Journal on the Rule of Law 2:111

Ledeneva A and Kurkchiyan M (eds.) (2000) Economic Crime in Russia. Kluwer

Ledeneva A (2001) Unwritten Rules: How Russia Really Works. Working Paper, Centre for European Reform

Ledeneva A (2002) Organized Crime in Russia Today in Galeotti M (ed.) (2002) Russian and Post-Soviet Organised Crime

Lenin V (1964) Collected Works Vol. 28. Progress Publishers

Lenin V (1970) The State and Revolution. Progress Publishers

Marx K (1859) Contribution to a Critique of Political Economy

Marx K and Engels F (1977) Selected Works Vol. III (Progress edition)

Marx K and Engels F (1875) Critique of the Gotha Programme. Progress Publishers (1970)

McDonald T (2011) Face to the Village: The Riazan Countryside under Soviet Rule, 19211930. University of Toronto Press

Medvedev R (2000) Post-Soviet Russia: A Journey through the Yeltsin Era. Columbia University Press 
North D (2005) Understanding the Process of Economic Change. Princeton University Press

Owen T (1991) The Corporation under Russian Law 1800-1917: A Study in Tsarist Economic Policy. Cambridge University Press

Pashukanis E (2009) The General Theory of Law and Marxism. Transaction Books

Posner R (1970) Economic Analysis of Law. Aspen Publishers

Posner R (1998) Creating a Legal Framework for Economic Development. 13 World Bank Research Observer 13:1

Reddaway P and Glinski D (2001) The Tragedy of Russia's Reforms: Market Bolshevism against Democracy. United States Institute of Peace Press

Renner K (1949) The Institutions of Private Law and their Social Functions, transl. Agnes Schwarzchild (ed) Routledge \& Keegan Paul

Roland G (2000) Transition and Economics, Politics, Markets and Firms. MIT Press

Sachs J and Pistor K (eds.) (1997) The Rule of Law and Economic Reform in Russia. Westview Press

Shleifer A and Treisman D (2004) A normal country. Foreign Affairs 83:20.

Smith G (1996) Reforming the Russian Legal System. Cambridge University Press

Stigler G (1966) The Theory of Price. Macmillan

Stiglitz J (1994) Whither Socialism? MIT Press

Supiot, A (2015) La gouvernance par les nombres. Fayard

Tomson W (2005) Putting Yukos in Perspective. Post-Soviet Affairs 21:159.

Treisman D (2010) “Loans for Shares” Revisited. NBER Working Paper No. 15819

Varian H (1974) Distributive Justice, Welfare Economics and the Theory of Fairness. Philosophy and Public Affairs 4:223

Volkov V (2002) Violent Entrepreneurs. Cornell University Press

World Justice Project (2014) WJP Rule of Law Index 2014. Available at:

http://data.worldjusticeproject.org/ (last consulted 22 May 2015) 